\title{
Respon Pertumbuhan Tanaman Padi Inpari 30 (Oryza sativa L.) akibat Kekeringan, Pemupukan $\mathbf{N}$ dan $\mathrm{K}$ \\ (Response of Growth in Inpari 30 Rice (Oryza sativa L.) to Drought, $N$ and $K$ Fertilizer)
}

\author{
Sofiana Yasrifah ${ }^{1 *}$, Cut Nur Ichsan ${ }^{2}$, Nanda Mayani ${ }^{2}$ \\ ${ }^{1}$ Mahasiswa Jurusan Agroteknologi, Fakultas Pertanian, Universitas Syiah Kuala \\ ${ }^{2}$ Staf Dosen Jurusan Agroteknologi, Fakultas Pertanian, Universitas Syiah Kuala \\ *Email: yasrifahs@gmail.com
}

\begin{abstract}
Abstrak. Penelitian ini bertujuan untuk mengetahui respon pertumbuhan tanaman padi inpari 30 akibat kekeringan, pemupukan $\mathrm{N}$ dan K. Penelitian ini dilaksanakan di Rumah Kaca 1 dan Laboratorium Fisiologi Tumbuhan Jurusan Agroteknologi, Fakultas Pertanian, Universitas Syiah Kuala yang berlangsung pada November 2020 sampai Februari 2021. Rancangan yang digunakan dalam penelitian ini adalah Rancangan Petak-Petak Terpisah (RPPT) $3 \times 2 \times 2$ dengan 3 ulangan. Petak utama kekeringan yang terdiri dari 3 taraf (Tanpa Kekeringan, Kekeringan Fase Vegetatif dan Kekeringan Fase Generatif), anak petak pemupukan N terdiri dari 2 taraf (100 kg N.ha ${ }^{-1}$ dan $\left.200 \mathrm{~kg} \mathrm{~N} \cdot \mathrm{ha}^{-1}\right)$ dan anak-anak petak pemupukan K yang terdiri dari 2 taraf $\left(75 \mathrm{~kg} \mathrm{~K} \cdot \mathrm{ha}^{-1+}\right.$ dan $\left.150 \mathrm{~kg} \mathrm{~K} \cdot \mathrm{ha}^{-1}\right)$. Data pada analisis ragam yang menunjukkan pengaruh dilanjutkan dengan Duncan New Multiple Range Test (DNMRT). Hasil penelitian menunjukkan bahwa kekeringan pada fase vegetatif dengan pemupukan $\mathrm{N} 100 \mathrm{~kg} \cdot \mathrm{ha}^{-1}$ dan $\mathrm{K} 75 \mathrm{~kg} \cdot \mathrm{ha}^{-1}$ dapat mempertahankan dan meningkatkan tinggi tanaman 30 HST dan 45 HST, jumlah anakan total 30 HST dan jumlah anakan produktif. Kekeringan fase generatif dengan pemupukan N $200 \mathrm{~kg} \cdot \mathrm{ha}^{-1}$ dan K $75 \mathrm{~kg} \cdot \mathrm{ha}^{-1}$ menunjukkan tinggi tanaman 30 HST dan 45 HST, jumlah anakan total 30 HST dan jumlah anakan produktif lebih baik. Pemberian pupuk N dan K yang sesuai terhadap pertumbuhan tanaman padi inpari 30 yang mengalami cekaman kekeringan pada fase yang berbeda dapat meningkatkan pertumbuhan tanaman padi Inpari 30.
\end{abstract}

Kata kunci: Anakan, Fase vegetaif, fase generatif, Inpari 30

\begin{abstract}
Abstrak. This study aims to determine the growth response of inpari 30 rice plants due to drought, $\mathrm{N}$ and $\mathrm{K}$ fertilizatiodosisn. This research was carried out at Greenhouse 1 and Plant Physiology Laboratory, Agrotechnology Department, Faculty of Agriculture, Syiah Kuala University which took place from November 2020 to February 2021. The study used a Split-Split Plot Design (SSPD) with 3 treatment factors of $3 \times 2 \times 2$ with 3 replications. Main plot of drought consisting of 3 levels (No Drought, Drought Vegetative Phase and Drought Generative Phase), sub-plots of N fertilization consisted of 2 levels (100 kg N.ha ${ }^{-1}$ and $\left.200 \mathrm{~kg} \mathrm{~N} . \mathrm{ha}^{-1}\right)$ and sub-sub plot of K fertilization consisting of 2 levels $\left(75 \mathrm{~kg} \mathrm{~K} \cdot \mathrm{ha}^{-1}\right.$ and $\left.150 \mathrm{~kg} \mathrm{~K} \cdot \mathrm{ha}^{-1}\right)$. The data on the analysis of variance that showed the effect was continued with Duncan's New Multiple Range Test (DNMRT). The results showed that drought in the vegetative phase with fertilization of $\mathrm{N} 100 \mathrm{~kg} \cdot \mathrm{ha}^{-1}$ and K $75 \mathrm{~kg}^{-\mathrm{ha}^{-1}}$ could maintain and increase plant height by $30 \mathrm{DAP}$ and $45 \mathrm{DAP}$, the total number of tillers $30 \mathrm{DAP}$ and the number of productive tillers. Drought of the generative phase with N $200 \mathrm{~kg} \cdot \mathrm{ha}^{-1}$ fertilization and K $75 \mathrm{~kg}$.ha ${ }^{-1}$ showed plant heights of $30 \mathrm{DAP}$ and $45 \mathrm{DAP}$, the total number of tillers was $30 \mathrm{DAP}$ and the number of productive tillers was better. The application of appropriate $\mathrm{N}$ and $\mathrm{K}$ fertilizers for the growth of Inpari 30 rice under drought stress at different phases can increase the growth of Inpari 30 rice plants.
\end{abstract}

Key Words: Tiller, The Vegetative Phase, The Generative Phase, Inpari 30

\section{PENDAHULUAN}

Tanaman Padi (Oryza sativa L.) merupakan tanaman budidaya terpenting dalam peradaban yang menjadi sumber pangan utama di Indonesia (Ichsan et al., 2021a,e). Hal ini di karenakan 90\% dari keseluruhan penduduk indonesia menjadikan beras sebagai makanan pokok yang memberikan pengaruh besar terhadap kestabilan ekonomi (Nikmah dan Musni, 2019). Produksi padi di Indonesia pada tahun 2020 adalah 55,16 juta ton GKG atau 31,63 juta ton beras yanag mengalami peningkatan 1,02\% dari tahun 2019 (BPS, 2020). Peningkatan produksi selalu diimbangi dengan meningkatnya populasi penduduk sehingga menyebabkan 
kebutuhan beras meningkat sedangkan jumlah lahan persawahan semakin berkurang. Hal ini merupakan suatu masalah tersendiri.

Permasalahan lainnya berupa cekaman abiotik seperti kekeringan memerlukan penangan spesifik melalui berbagai pendekatan (Ichsan et al., 2021b). Kekurangan pasokan air akibat rendahnya curah hujan dalam periode yang panjang sehingga menyebabkan kekeringan (Sujinah dan Jamil, 2016). Cekaman kekeringan sangat berdampak negatif bagi petani karena kekeringan dapat terjadi pada berbagai fase pertumbuhan tanaman padi (Ichsan et al., 2021c). Hal ini dapat mengakibatkan hasil padi menurun bahkan mengalami resiko kegagalan panen yang mengancam ketahanan pangan (Sugiarto et al., 2018). Perubahan morfologi dan fisiologi tanaman padi akibat kekeringan menyebabkan terhambatnya penyerapan nutrisi, pembesaran sel, penurunan aktivitas enzim serta penutupan stomata yang dapat mempengaruhi pertumbuhan dan hasil tanaman padi (Afrianingsih et al., 2018).

Kekeringan yang terjadi pada fase vegetatif tanaman padi mengakibatkan terhambatnya pertumbuhan akar dan daun sehingga menurunnya persentase jumlah anakan dan jumlah malai perumpun (Jati, 2020; Ichsan et al., 2021a,e). Diperkuat oleh Sulistyo et al. (2016), bahwa fase vegetatif yang mengalami cekaman kekeringan dapat menghambat pertumbuhan jumlah anakan, tinggi tanaman, dan jumlah daun. Selain itu, kekeringan yang terjadi pada fase vegetatif dapat menunda pembungaan sekitar 2-5 minggu (Hariyono, 2014; Ichsan et al., 2020a).

Kekeringan pada fase generatif berdampak serius terhadap hasil tanaman padi. Hal ini dikarenakan banyaknya fotosintat yang didistribusikan ke bagian generatif, yaitu bunga dan gabah berubah sehingga terjadi perubahan pada indeks panen (Nazirah, 2018). Tanaman padi yang megalami kekeringan pada fase generatif menyebabkan terjadinya penurunan hasil (Sujinah dan Jamil, 2016). Sejalan dengan pendapat Hariyono (2014), kekeringan pada fase generatif yaitu fase pembungaan dan pengisian biji dapat menurunkan hasil padi mencapai $50 \%$ dan $21 \%$. Diperkuat oleh Wening et al. (2019), fase generatif merupakan fase kritis tanaman padi terhadap cekaman kekeringan yang dapat menurunkan hasil hingga 13-35\% pada musim hujan dan $34-59 \%$ pada musim kering.

Hal ini dapat diatasi dengan pengelolaan air dan pemupukan. Sunawan dan Sugiarto (2020) menyatakan bahwa salah satu usaha untuk meningkatkan produktivitas tanaman melalui pemupukan. Hal ini dikarenakan eratnya kaitan antara ketersediaan air dan unsur hara bagi tanaman yang tersedia di dalam tanah. Langkah utama untuk mempertahankan pertumbuhan tanaman padi pada kondisi kekeringan dapat dilakukan melalui pemupukan Nitrogen dan Kalium. Subramanian et al. (2020) menunjukkan bahwa dengan meningkatkan dosis $\mathrm{N}$ dari $125 \mathrm{~kg} \cdot \mathrm{ha}^{-1}$ menjadi $200 \mathrm{~kg} \cdot \mathrm{ha}^{-1}$ dapat meningkatkan pertumbuhan dan hasil seperti tinggi tanaman, indeks luas daun, anakan, dan berat gabah permalai lebih tinggi.

Unsur hara lainnya yang dibutuhkan tanaman padi dalam jumlah besar adalah Kalium (K) (Ramadhan et al., 2020). Tanaman padi membutuhkan K 235,4 kg KCl.ha ${ }^{-1}$ dengan

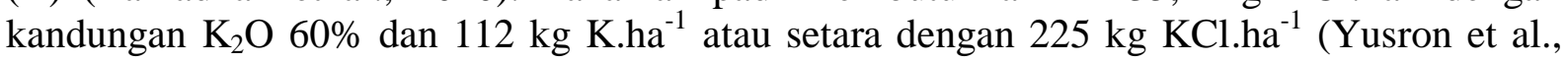
2018). Peran positif dari unsur hara $\mathrm{K}$ pada kondisi cekaman kekeringan dapat meningkatkan ketahanan tanaman padi melalui pengaruhnya terhadap proses fisiologis dan biokimiawi. Hal ini dibenarkan oleh Zain dan Ismail (2016) bahwa K dapat memberikan pengaruh yang positif terhadap kekeringan yang terjadi pada pertumbuhan dan perkembangan tanaman padi karena memiliki pengaruh pada aktivitas enzim, sintesis protein, dan fotosintesis. Sesuai dengan penelitian Hartati et al. (2018), fotosintat dapat terdistribusi dengan baik akibat peran dari kalium dalam translokasi fotosintat dari daun menuju tempat penyimpanan (biji). Hakim et al. (2020) membuktikan bahwa pemberian pupuk K pada fase generatif dengan dosis $75 \mathrm{~K} \mathrm{kg.ha}$

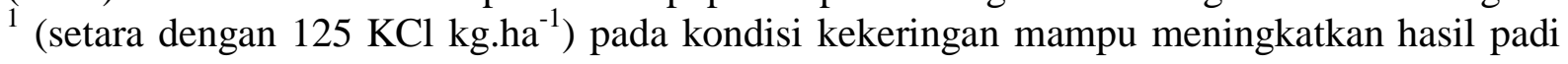


sebesar 57\%. Penambahan pupuk K $150 \mathrm{~kg} \cdot \mathrm{ha}^{-1}$ mempengaruhi pertumbuhan tinggi tanaman dan diameter batang pada padi ciherang yang terus meningkat (Pasaribu et al., 2013).

Berdasarkan uraian diatas dilakukan penelitian pengaruh kekeringan, pemupukan $\mathrm{N}$ dan $\mathrm{K}$ terhadap pertumbuhan tanaman padi dengan tolak ukur interaksi ketiga faktor terhadap tinggi tanaman, jumlah anakan total dan jumlah anakan produktif tanaman padi.

\section{METODE PENELITIAN}

Penelitian berlangsung selama 4 bulan mulai November 2020 hingga Februari 2021 di Rumah Kaca 1 serta Laboratorium Fisiologi Tumbuhan Fakultas Pertanian Universitas Syiah Kuala. Rancangan penelitian ini adalah rancangan petak - petak terpisah (RPPT) pola faktorial $3 \times 2 \times 2$ dengan 3 ulangan. Faktor kekeringan terdiri dari $S_{0}$ tanpa kekeringan, $S_{1}$ kekeringan fase vegetatif, dan $S_{2}$ kekeringan fase generatif yang menjadi petak utama. Anak petak pemupukan nitrogen terdiri dari $\mathrm{N}_{1} 100 \mathrm{~kg} \cdot \mathrm{ha}^{-1}$ dan $\mathrm{N}_{2} 200 \mathrm{~kg} \cdot \mathrm{ha}^{-1}$. Sedangkan anakan dari anak petak berupa dosis kalium $\mathrm{K}_{1} 75 \mathrm{~kg} \mathrm{~K} \cdot \mathrm{ha}^{-1}$ dan $\mathrm{K}_{2} 100 \mathrm{~kg} \mathrm{~K} \cdot \mathrm{ha}^{-1}$. Bibit padi berumur 12 HSS ditanam pada pot berdiameter $45 \mathrm{~cm}$ dengan ketinggian $40 \mathrm{~cm}$ yang diisi $10 \mathrm{~kg}$ tanah Entisol. Pemupukan diberikan sebagai pupuk dasar berupa pupuk SP-36 2,8 g.pot ${ }^{-1}$ setara dengan $150 \mathrm{~kg} \mathrm{P.ha}{ }^{-1}$. Sedangkan pupuk N dan K diaplikasikan pada saat tanaman berumur 7 , 30 dan 60 HST. Pengairan dilakukan sesuai dengan perlakuan, pengamatan dilakukan terhadap tinggi tanaman, jumlah anakan dari umur 15 sampai 60 HST.

\section{HASIL DAN PEMBAHASAN}

Berdasarkan hasil uji F (analisis ragam) interaksi antara kekeringan, pemupukan $\mathrm{N}$ dan $\mathrm{K}$ menunjukkan bahwa terdapat interaksi yang sangat nyata terhadap tinggi tanaman 30 HST dan 45 HST, jumlah anakan 30 HST dan jumlah anakan produktif. Namun tidak terdapat interaksi terhadap jumlah daun. Tinggi tanaman 30 dan 45 HST dapat dilihat pada gambar 1.

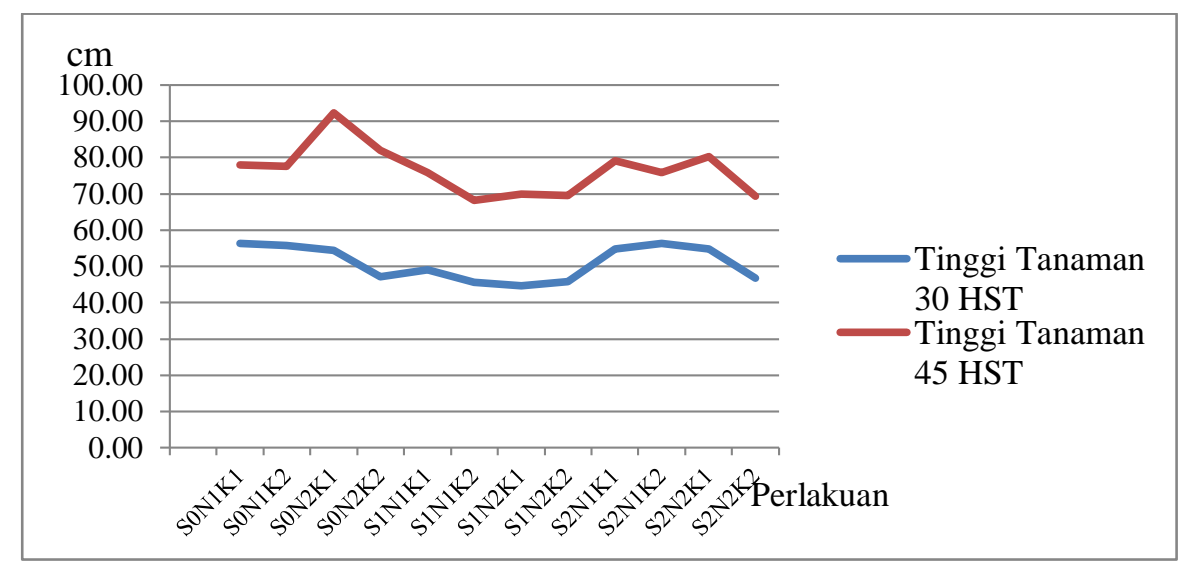

Gambar 1. Grafik Tinggi Tanaman 30 HST dan 45 HST akibat kekeringan, pemupukan N dan K

Terdapat perubahan tinggi tanaman padi umur 30 dan 45 HST akibat interaksi kekeringan dengan dosis nitrogen dan kalium yang berbeda. Kekeringan fase vegetatif dengan dosis $100 \mathrm{~kg}$ perhektar dan $75 \mathrm{~kg}$ perhektar, tinggi tanaman lebih rendah dibanding tinggi tanaman pada kondisi kekeringan fase generatif dengan dosis $100 \mathrm{~kg} \mathrm{~N}$ dengan dosis $150 \mathrm{~kg}$ kalium (gambar 1). Pada dosis $200 \mathrm{~kg} \mathrm{~N}$ perhektar dan $75 \mathrm{~kg} \mathrm{~K}$ perhektar tanpa kekeringan fase vegetatif tinggi tanaman lebih baik dibanding yang mengalami kekeringan fase vegetatif. 
Hal ini dikarenakan nitrogen mempengaruhi pertumbuhan vegetatif tanaman (Derial et al., 2016; Octa 2015; Haque et al., 2013). Nitrogen dapat mempengaruhi pembelahan dan pembesaran sel (Asmuliani et al., 2021). Sedangkan kalium dapat meningkatkan hasil fotosintesis yang merupakan bahan baku untuk pembentukan sel (Anshoruddin et al., 2017). Tanaman padi yang mengalami kekeringan mengakibatkan perubahan morfologi (Violita et al., 2017; Ichsan et al., 2021c). Ketersediaan air pada fase pertumbuhan mempengaruhi pertumbuhan padi (Boromeu et al., 2018). Kekeringan menyebabkan perubahan pada tinggi tanaman padi (Kumar et al., 2009; Ichsan et al., 2021d; Ilyani et al., 2017; Sari dan Barunawati, 2019). Kekeringan menyebabkan rusaknya membran sel (Yang et al., 2016). Pemupukan N dan K mempengaruhi pertumbuhan padi (Zaman et al., 2015; Nge et al., 2016). Kemudian nitrogen dapat meningkatkan tinggi tanaman (Kumara dan Haffeel 2019; Ali et al., 2019). Adapaun jumlah anakan total dan anakan produktif terdapat pada Gambar 2.

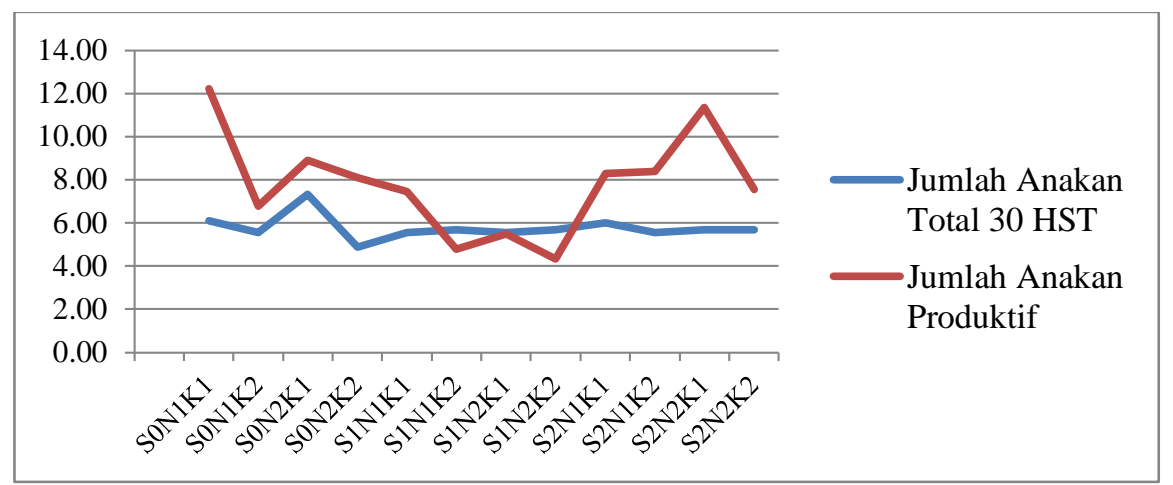

Gambar 2. Grafik jumlah anakan total 30 HST dan jumlah anakan produktif akibat kekeringan, pemupukan $\mathrm{N}$ dan $\mathrm{K}$

Interaksi kekeringan dosis $\mathrm{N}$ dan $\mathrm{K}$ berpengaruh terhadap jumlah anakan total umur 30 HST. Perlakuan tanpa kekeringan dengan dosis N $200 \mathrm{~kg}$ perhektar dan K $75 \mathrm{~kg}$ perhektar menyebabkan jumlah anakan meningkat (gambar 2).

Pada kondisi kekeringan fase vegetatif dengan pemupukan N $100 \mathrm{~kg}$ perhetar dan $\mathrm{K} 75$ $\mathrm{kg}$ perhektar menunjukkan jumlah anakan yang tidak berbeda nyata dengan dosis pupukan $\mathrm{K}$ yang lebih tinggi. Hal ini menunjukkan bahwa kekeringan fase generatif dengan tingkat pemupukan yang rendah tidak berpengaruh terhadap jumlah anakan. Hal ini dikarenakan jumlah anakan merupakan pengaruh dari genetik dari varietas sehingga pengaruh pemupukan tidak terlihat berbeda kecuali pada kekeringan fase generatif. Pada fase generatif berupa pembentukan malai yang ditandai juga dengan perubahan tinggi tanaman menunjukkan perbedaan yang nyata. Hal ini dikarenakan pemberian $\mathrm{N}$ dan $\mathrm{K}$ mampu memacu pertumbuhan pada fase generatif akibat peran $\mathrm{N}$ dalam pembentukan protein yang merupakan komponen utama dari sel yang mempengaruhi jumlah anakan, panjang tanaman, luas daun dan berat kering tanaman (Qibtiyah 2019; Tando 2018; Asmuliani et al., 2021; Rumanti et al., 2020; Saputra et al., 2016). Pemupukan kalium pada kondisi kekeringan membantu meningkatkan pertumbuhan tanaman padi (Zain et al., 2014). Perubahan teknik pemupukan pada kondisi kekeringan diperlukan untuk meningkatkan ketahanan tanaman terhadap kekeringan (Ichsan et al., 2021d). Diperlukan upaya meningkatkan ketahanan tanaman pada kondisi fase vegetatif dan awal vegetatif melalui perubahan teknik pemupukan yang dapat meningkatkan ketahanan tanaman terhadap kekeringan. 


\section{KESIMPULAN DAN SARAN}

Kekeringan fase vegetatif dengan pemupukan N 100 kg.ha ${ }^{-1}$ dan $\mathrm{K} 75 \mathrm{~kg} \cdot \mathrm{ha}^{-}{ }^{1}$ dapat mempertahankan dan meningkatkan tinggi tanaman padi Inpari 30 umur 30 dan 45 HST, jumlah anakan total 30 HST dan jumlah anakan produktif. Kekeringan fase generatif dengan pemupukan N $200 \mathrm{~kg} \cdot \mathrm{ha}^{-1}$ dan $\mathrm{K} 75 \mathrm{~kg} \cdot \mathrm{ha}^{-1}$ menghasilkan peetumbuhan yang baik terhadap tinggi tanaman 30 dan 45 HST, jumlah anakan total 30 HST dan jumlah anakan produktif.

Berdasarkan penelitian yang dilakukan disarankan untuk melakukan penelitian selanjutnya dilapangan dengan dosis pupuk $\mathrm{N}$ dan $\mathrm{K}$ dan kekeringan pada berbagai fase pertumbuhan dan hasil beberapa varietas padi yang memiliki jumlah anakan lebih banyak dan sedikit.

\section{DAFTAR PUSTAKA}

Afrianingsih, S., Susanto, U dan Andriani, N. R. 2018. Toleransi genotipe padi (Oryza sativa L.) pada fase generatif terhadap cekaman kekeringan. Jurnal Produksi Tanaman, 6(3), pp. $355-363$.

Ali I., Khan, A. A., Munsif, F., He, L., Khan, A., Ullah, S., Saeed, W., Iqbal, A., Adnan, M. and Ligeng, J. 2019. Optimizing rates and application time ofpotassium fertilizer for improving growth, grainnutrients content and yield of wheat crop. Open Agriculture, 4, pp. $500-508$

Ansoruddin, S., Ningsih, S. dan Siagian, H. H. 2017. Respon pemberian dosis pupuk KCl dan dosis pupuk kandang sapi terhadap pertumbuhan bibit tanaman Gaharu (Aquilaria crassna) di Polibag. Jurnal Penelitian Pertanian Bernas, 13(1).Issn 0216-7689.

Asmuliani R., Darmawan, M., Sudiarta, I. M. dan Megasari, R. 2021. Pertumbuhan tanaman padi (Oryza sativa L.) varietas ponelo padaberbagai dosis pupuk nitrogen dan jumlah benih per lubang tanam. Jurnal Pertanian Berkelanjutan, 9(1), pp. $10-17$.

Baral B. R., Baral, K. R., Singh, U., Pande, K. R., Sah, S. K., Gaihre, Y. K. and Thapa, Y. B. 2020. Increasing nitrogen use efficiency in rice through fertilizer application method under rainfed drought conditionsin Nepal. Nutr Cycl Agroecosyst, pp. 1 - 12.

Borromeu M. R., Sadimantara, I. G. R. dan Pasolon, Y. B. 2018. Respon pertumbuhan dan produksi beberapa kultivar padi gogo lokal sultra terhadap volume pemberian air. Jurnal Berkala, 6(2), pp. 25 - 36.

BPS. 2020. Indonesia Dalam Angka. BPS, Jakarta.

Deria, A. H., Kuswanta, F. H. dan Muhajir, U. 2016. Pengaruh pemupukan nitrogen dan sistem olah tanah tanah jangka panjang terhadap pertumbuhan dan produksi padi gogo (Oryza sativa L.) tahun ke-27 di lahan Politeknik Negeri Lampung. Jurnal Agrotek Tropika. 4(1).

Hakim, M. S., Dewanti, P., Hartatik, S., Slameto dan Handoyo, T. 2020. Efek pemberian potassium terhadap recovery tanaman padi (Oryza sativa L.) setelah cekaman kekeringan. Jurnal Ilmu Dasar, 21(2), pp. 115 - 122.

Haque, M. D. A. 2013. Effect of different levels of nitrogen and plant spacing on the yieldof transplant aman Rice CV. Brri Dhan 52. Thesis. Bangladesh Agricultural University. Mymensingh.

Hariyono. 2014. Keragaan vegetatif dan generatif beberapa varietas tanaman Padi (Oryza sativa L.) terhadap cekaman kekeringanpada fase pertumbuhan yang berbeda. Journal of Agro Science, 2(1), pp. 20 - 27. 
Hartati, Suryono dan Purnomo, D. 2018. Effectiveness and efficiency of potassium fertilizer application to increase the production and quality of rice in entisols.IOP Conf. Series.Earth and Enviromental Science, 142, pp $1-9$.

Ichsan, C. N. 2021a. Perubahan karakter morfo-agronomis dan fisiologis tanaman padi (oryza sativa 1.) Pada kondisi stres air. Disertasi. Universitas Syiah Kuala. Banda Aceh, Indonesia

Ichsan, C. N., Sulaiman, M. I., \& Andini, R. 2021b. Role of plant genetic resources in encountering climate change challenge. In IOP Conference Series: Earth and Environmental Science (Vol. 711, No. 1, p. 012008). IOP Publishing.

Ichsan, C. N. 2021c. Morpho-agronomic traits and balance of sink and source of rice planted on upland rainfed. In IOP Conference Series: Earth and Environmental Science (Vol. 667, No. 1, p. 012108). IOP Publishing.

Ichsan, C. N. 2021d. Morphological and physiological change of rice (Oryza sativa L.) under water stress at early season. In IOP Conference Series: Earth and Environmental Science (Vol. 644, No. 1, p. 012030). IOP Publishing.

Ichsan, C. N., Basyah, B., Zakaria, S., \& Efendi, E. 2021e. Alteration of dry matter accumulation under soil moisture fluctuation stress in rice (Oryza sativa L.). AJCS 15(05), 757-763

Jati, W. A. 2020. Pengaruh cekaman kekeringan fase vegetatifterhadap kualitas benih padi (Oryza sativa L.). Skripsi. Program Studi Agronomi. Fakultas Pertanian. Universitas Sriwijaya.

Kumar, A., Verulkar, S., Dixit, S., Chauhan, B., Bernier, J., Venuprasad, R., Zhao, D., Shrivastava, M.N., 2009. Yield and yield-attributing traits of rice (Oryza sativa L.) under lowland drought and suitability of early vigor as a selection criterion. Field Crop Res, 114, pp. 99-107.

Kumara, K. H. C. H dan Hafeel, R. F. 2019. Effect of different soil nitrogen levels on growth, yield and grain filling rate of rice (Oryza sativa L.) elite breeding line at 081078 and variety AT 362. Tropical Agricultural Research and Extonsion, 22 (1 dan 2), pp. 1 - 9.

Nazirah, L. 2018. Teknologi Budidaya Padi Toleran Kekeringan. Aceh: Sefa Bumi Persada.

Nge, L. 2016. Assessment of nitrogen and potassium fertilization on rice yield in maubin township. Thesis. Department of Soil and Water Science. Yezin Agricultural University. Nay Pyi Taw, Myanmar.

Nikmah, K. dan Musni, M. 2019. Peningkatan kemampuan serapan nitrogen (N) tanaman padi (Oryza sativa L.) melalui mutasi gen secara kimiawi. Agritrop, 17(1), pp. $1-20$.

Octa, S. S. 2015. Pengaruh Pemupukan Nitogen (N) dan Jarak Tanam Terhadap Pertumbuhan, Hasil dan Kualitas Hasil Padi Japonica Varietas Hitomebore di Daerah Tropik. Skripsi. Institut Pertanian Bogor. Bogor.

Pasaribu, A., Kardhinata, E. H. dan Bangun, M. K.. 2013. Uji beberapa varietas padi sawah irigasi (Oryza sativa L.) dan aplikasi pupuk kalium $(\mathrm{KCl})$ untuk meningkatkan produksi dan ketahanan rebah. Jurnal Online Agroekoteknologi. 1(2), pp. 45 - 57.

Qibtiyah, M. 2019. Efektifitas aplikasi waktu pemberian biourine plus dan dosis pupuk urea terhadap peningkatan pertumbuhan dan produksi padi (Oryza sativa L.). Agroradix, $2(2)$, pp. $44-51$.

Ramadhan, G. R., Usmadi dan Fanata, W. I. D. 2020. Pengaruh pemupukan kalium terhadap pertumbuhan dan hasil beras kepala pada Padi (Oryza sativa L.) Varietas Merah Wangi. Jurnal Ilmu Dasar, 21(1), pp. 61 - 66. 
Rumanti, I. A., Koesrini, Sosiawan, H. dan Rina, Y. 2020. Uji adaptasi dan seleksi varietas partisipatif terhadap galur - galur padi toleran rendaman dan kekeringan di lahan rawa lebak. J. Agron. Indonesia, 48 (2), pp. 118 - 126.

Saputra, I. 2016. Efek dosis pupuk nitrogen dan varietas terhadap efisiensi pemupukan, serapan hara $\mathrm{N}$ dan pertumbuhan padi lokal Aceh dataran rendah. Jurnal Penelitian Agrosamudra, 3(2), pp. $61-71$.

Sari, T. R dan Barunawati, N. 2019. Pengaruh sumber nitrogen berbeda dan tingkat kapasitas lapang terhadap hasil padi (Oryza sativa L.) varietas situ bagendit. Jurnal Produksi Tanaman, 7 (8), pp. 1410 - 1417.

Subandi. 2013. Peran dan pengelolaan hara kalium untuk produksi pangan di Indonesia. Pengembangan Inovasi Pertanian. 6(1), pp. $1-10$.

Subramanian E., C. Aathithyan, V.B. raghavendran and S. Vijayakumar. 2020. Optimization of nitrogen fertilization for aerobic rice (Oryza sativa L.). Indian Journal of Agronomy, 65(2), pp. $180-184$.

Sugiarto, R., Kristanto, B. A. dan Lukiwati, D. R. 2018. Respon pertumbuhan dan produksi padi beras merah (Oryza nivara) terhadap cekaman kekeringan pada fase pertumbuhan berbeda dan pemupukan nanosilika. Jurnal Agro Complex. 2(2): 169 - 179.

Sujinah dan Jamil, A. 2016. Mekanisme Respon tanaman padi terhadap cekaman kekeringan dan varietas Toleran. Iptek Tanaman Pangan. 11(1): 1 - 8.

Sulistyo, R., Yunus, A., dan Nandariyah. 2016. Keragaman padi Ciherang M2 hasil radiasi Gamma pada stres kekeringan. Agrotech Res J, 5(1), pp. 19-23.

Sunawan dan Sugiarto. 2020. Aplikasi Dosis Pupuk Urea dan umur bibit terhadap pertumbuhan dan hasil tanaman padi Ketan (Oryza sativa glutinous L.). Jurnal Folium, 3(2), pp. $96-107$.

Tando, E. 2018. Upaya efisiensi dan peningkatan ketersediaan nitrogen dalam tanah serta serapan nitrogen pada tanaman padi sawah (Oryza sativa L.). Balai Pengkajian Teknologi Pertanian, 18(2), pp. $171-180$.

Violita, I. L. E. Putri dan M. R. Ritonga. 2017. Respon pertumbuhan dan kadar klorofil beberapa varietas tanaman padi (Oryza sativa L.) pada kondisi kekeringan. Jurnal Biosains, 1(2), pp. $33-43$.

Wening, R. H., Purwoko, B. S., Suwarno, W. B., Rumanti, I. A. dan Khumaida, N. 2019. Seleksi simultan karakter daun mengering dan produktivitas pada galur-galur padi. Jurnal Agronomi Indonesia, 47(3), pp. 232 - 239.

Yang, Y., Guan, H., Batelaan, O., McVicar, T. R., Long, D., Piao, S., Liang, W., Liu, B., Jin, Z. and Simmons, C. T. 2016. Contrasting responses of water use efficiency to drought across global terrestrial ecosystems. Sci Rep, 6, pp. (23284).

Yusron, M., Wati, R. S., Setyorini, D. dan Mutmainah, H. 2018. Penentuan dosis pupuk lahan sawah berdasarkan status hara fosfor dan kalium dilahan sawah Kabupaten Pandeglang. Jurnal Pengkajian dan Pengembangan Teknologi Pertanian, 20(2), pp. 149 - 158.

Zain, N. A. M., Ismail, M. R., Puteh, A., Mahmood, M. and Islam, M. R. 2014. Drought Tolerance and Ion Accumulation of Rice Following Application of Additional Potassium Fertilizer. Communications in Soil Science and Plant Analysis, 45 (19): 2502 $-2514$.

Zain, N. A. M. and Ismail, M. R. 2016. Effects of potassium rates and types on growth, leaf gas exchange and biochemical changes in rice (Oryza sativa L.) planted under cyclic water stress. Agricultural Water Management, 164, pp. 83 - 90. 
Zaman, U., Ahmad, Z., Farooq, M., Saeed, S., Ahmad, M. and Wakeel, A. 2015. Potassium fertilization may improve stem strength and yield of basmati rice grown on nitrogenfertilized soils. Jurnal Agri. Scieince, 52(2), pp. 437 - 443. 